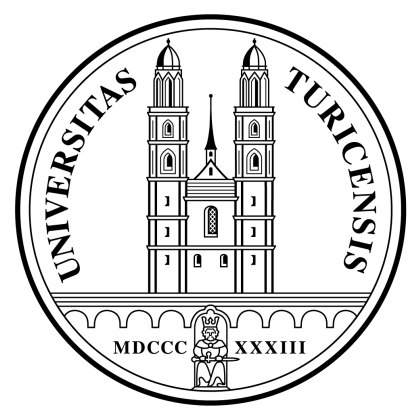

Institute for Empirical Research in Economics

University of Zurich

Working Paper Series

ISSN 1424-0459

Working Paper No. 57

Europe's Eminent Economists:

A Quantitative Analysis

Reiner Eichenberger and Bruno S. Frey

September 2000 
September 13, 2000

\title{
Europe's Eminent Economists: A Quantitative Analysis
}

\author{
Reiner Eichenberger and Bruno S. Frey*
}

\section{Introduction}

Where do Europe's eminent economists reside, and what determines a country's output of such scholars? The literature on the "economics of economics", as the analytical investigation into economics might be called, is astonishingly silent when it comes to such questions. This is especially true with respect to empirical work on economists in European countries. Therefore, this paper makes a first attempt at investigating Europe's eminent economists.

A natural starting point for such an analysis is provided by Mark Blaug's unrivalled Who's Who in Economics (Blaug 1999, 1986, Blaug and Sturges 1983). This opus coined the term “eminent economist"- a scholar being cited most often in economics journals - and provides a sample of 1000 such scholars. It is also for this reason that most empirical work on eminent economists refer to Blaug's data (see, e.g., De Lorme and Kamerschen 1987, Frey and Pommerehne 1988).

However, for our purposes, Blaug's Who's Who does not provide satisfactory data for three reasons: ${ }^{1}$ 
First, Blaug's citation counts are based on quite long periods of time. The third edition (Blaug 1999), to which we refer in the following, is based on the individuals' total number of citations in the period 1984-1996. Therefore, these data are biased in favor of older economists who had the chance of being cited during the whole period.

Second, Blaug's basic set, from which he selected the eminent economists, appears to be quite small. He starts from a set of 1,400 scholars on a world-wide basis and ends with 263 Europeans among the approximately 1,000 most often cited economists world-wide (who responded to his mailings). Assuming that the European ratio in the basic sample and in the selection of eminent economists is the same, it may be inferred that the basic set comprises only about 368 Europeans.

Third, Blaug does not inform the reader how he selected the basic set. But he seems to have missed a significant number of economists who are more often cited than those included in his Who's Who in Economics. ${ }^{2}$ Therefore, one may suspect that Blaug's selection method for the basic set produces a bias, although his next step, the selection of the eminent scholars from the basic set, is based on purely objective principles. Moreover, analyses based on Blaug's data disregard those scholars who did not respond to Blaug's mailings, i.e. who were unwilling, or unable, to be included in his book.

Therefore, we collect new data on citations of European economists which are better suited to analyzing the following aspects of the distribution of economists according to countries:

\footnotetext{
${ }^{*}$ The authors are grateful to Stephan Meier for help in the statistical research.

${ }^{1}$ Of course, Who's Who in Economics goes well beyond listing the set of most frequently quoted economists. It also provides an account of their contribution to economics (according to the respective scholar's own evaluation) as well as a list of the major articles and books they have had published.

${ }^{2}$ Examples are for the United Kingdom Andrew Harvey, John Vickers and Nicholas Crafts, for France SergeChristophe Kolm, Christian Gourieroux and Roger Guesnerie, for Germany Werner Güth, Horst Siebert and Hans-Werner Sinn, for Italy Giuseppe Bertola, Francesco Giavazzi and Vittorio Grilli, for Belgium Mathias Dewatripont and Philippe Weil, for the Netherlands Eric van Damme, Peter Wakker and Peter Nijkamp, for Sweden Lars Calmfors, for Denmark Søren Johansen and Svend Hylleberg, for Norway Michael Hoel, for Spain Albert Marcet, and for Switzerland Richard Baldwin, Jaime de Melo and Paul Bairoch.
} 
(1) What is the importance of various countries in the total output produced by economic science, as measured by the citations of eminent economists? In order to answer this question, we also identify the 20 most eminent (i.e. most often cited) economists.

(2) Does the number of eminent economists produced depend on the genetic endowment available? If so, one would expect that the distribution of eminent economists mirrors the size of the population of the various countries.

(3) Does the number of eminent economists produced depend on economic capacity? If so, one would expect that the distribution of eminent economists mirrors the distribution of GNP among the various nations.

The analysis provided here deviates in various respects from the information contained in Blaug's Who's Who in Economics:

- The basis from which the most often cited economists are calculated is extended, allowing us to identify eminent economists neglected by Blaug.

- We consider a shorter, but more recent period of time. Thus, our data reflect the current situation more accurately.

- A ranking of the top twenty most often cited European economists is presented (Blaug only identifies the set of eminent economists).

- It is analyzed how the distribution of eminent economists is influenced by the countries' size of population and per capita economic output. 
We consider only living Europeans. Blaug, in contrast, considers the whole world and also includes deceased scholars. ${ }^{3}$

Section II briefly discusses measurement aspects. The distribution of eminent economists is presented according to various sets of countries in section III. Sections IV and V analyzes how the number of eminent economists depends on the size of the population, and the economic capacity, respectively, of the various countries. Section VI focuses on the top 20 economists. Section VII looks at some other measures of eminence and the respective country rankings. The robustness of our results is discussed in section VIII. The final section offers conclusions.

\section{Measurement Aspects}

Following Blaug, we define eminent economists according to the number of citations provided by the Social Science Citation Index (SSCI). It lists citations from about 200 economics journals, as well as from several hundred journals in the other social sciences. While the SSCI provides a unique data base for analyses of the academic impact of scholars, its shortcomings are well known; in particular, citations are only attributed to the first author of a publication. Nevertheless, the number of citations in the SSCI is well correlated with winning the Nobel Prize in Economics (see e.g. Quandt 1976, Grubel 1979, Lindbeck 1999), being elected to offices in the leading professional associations, such as the American Economic Association, the International Economic Association and the European Economic

\footnotetext{
${ }^{3}$ But in the period $1984-1996$, with very few exceptions, all eminent economists were located either in North America (68.2 percent) or in Europe (26.1 percent). 2.8 percent were in Australia and New Zealand, 0.9 in Japan, and 1.4 percent in Israel. The remaining 0.8 percent consisted of Brazil, Chile, Hong Kong, India, Indonesia, Korea, Mexico, and Russia, which hosted only one eminent economist ( 0.1 percent), each.

${ }^{4}$ Our focus on citations rather than publications is an important difference between our work and some recent publications, which focus on the publications of European economists (e.g. Bommer and Ursprung 1998, Kalaitzidakis, Mamuneas and Stengos 1999, Kocher and Sutter 2000).
} 
Association, as well as gaining tenure at reputed universities and earning above average university salaries. $^{5}$

We concentrate on the years 1993-1996. For this four year period there are still paper copies of the SSCI available, which - perhaps counter-intuitively to some readers - lend themselves much easier to quantitative analyses than the electronic version of later years.

It is impossible to count the citations of all living European economists. We therefore restrict our count to a carefully selected basic set in order not to miss frequently cited economists already at this initial stage. To minimize the chances of such mistakes occurring we constituted a wide basic set covering publication activities and citation incidences at different periods of time by relying on three elements: first, all the 812 economists with a European main affiliation, who published in the period 1993-96 in the leading economics journals with a broad scope (American Economic Review, Journal of Political Economy, Quarterly Journal of Economics, Econometrica, Review of Economics and Statistics, and Review of Economic Studies, and in order to well capture the Europeans, the Economic Journal, European Economic Review and Kyklos, for the ranking of these journals see Laband and Piette 1994); second, all the 508 European economists who were identified by Eichenberger and Meier (1996) as either having published in the period 1988-90 in the above mentioned journals (with the exception of the Review of Economic Studies) or having been frequently cited in the same period; third, all the 209 European economists included in Blaug (1986). As the three sets are partly overlapping, this gives a basic set of 1304 European economists, i.e. economists with their main affiliation in Europe at our key-date January 1, 1995 (for more details on the citation counts, see Arpagaus 1998).

\footnotetext{
${ }^{5}$ Among the extensive literature, see e.g. the publications by Laband (1985), De Lorme and Kamerschen (1988), Frey and Pommerehne (1988), Dusansky and Vernon (1998), Eichenberger, Arpagaus and Meier (2000).
} 
We counted the citations of all these economists and selected the most frequently cited ones. Imposing a cut-off of more than 100 citations over the period 1993-96, a set of 160 eminent European economists emerged.

The breadth of our basic set cannot only be seen by comparing its size (1304) to Blaug's set (with an estimated 368 entries), but also by the high cut off point imposed on our selection. While we count an economist as eminent if he is cited at least 25 times per year (on average over the period 1993-96), Blaug (1986) includes economists who got at least "two to three citations per year" (on average over the period 1972-83; see Blaug 1999, p. x). ${ }^{6}$

\section{Eminent Economists according to Countries}

Table 1 exhibits in its second and third column the absolute number, and the percentage of the total number, of eminent economists in the period 1993-96 according to the country they worked in.

\section{TABLE 1 HERE}

The table reveals the following main results:

(1) Economists active in the United Kingdom clearly dominate. More than half of all eminent European economists (57 percent) are located in that country ${ }^{7}$. No other European country has a share of more than 10 percent of all eminent economists. The median share of these fourteen countries (excluding the UK) lies between 3 percent (for Sweden) and 2 percent (for Spain). UK's share is seven times larger than that of the next best country, France ( 8

\footnotetext{
${ }^{6}$ Unfortunately, Blaug does not inform the reader about his cut off point for the third edition. However, the third edition (1999) uses the same selection methods as the second edition (1986). It should also be noted that we counted all citations of an individual, while Blaug does not count self-citations. However, for eminent economists, self-citations do not play a decisive role for the total number of citations.

${ }^{7}$ Blaug (2000) identifies an even larger percentage (64), which may be due to an over-representation of economists from the UK in the basic sample he starts with. The percentages for the other countries are quite
} 
percent). This dominance of UK economists among the leading European economists is not easy to reconcile with the concern presently raised about the position of UK economists (see the special issue of the Economic Journal, June $2000^{8}$ ).

(2) The large European countries (all with a population of more than 39 million) are well placed. France is ranked 2, Germany 4, Italy 5, and only Spain (ranked 9) is trailing behind. Overall, these four large European countries make up 20.5 percent of all eminent European economists.

(3) Almost half, namely 6 out of 15 countries, have only 1 or 2 eminent economists.

(4) Many European countries do not have any eminent economist. Among them are three members of the European Union (Finland, Luxembourg and Portugal) as well as a major world power, Russia. With the exception of Hungary, none of the Central and East European Countries (CEECs) seeking admission to the EU - the "pre-ins" Poland, the Czech Republic, Slovenia and Estonia, and the other applicants Bulgaria, Romania, Slovakia, Latvia and Lithuania - can boast having any eminent economist. The same holds for the further EU applicants Cyprus and Malta, as well as for the tiny states of Monaco, Liechtenstein, Andorra and San Marino.

Points (3) and (4) accentuate the concentration of eminent economists in just a few countries.

(5) Some small countries do well. If "small" is defined as having a population of less than 10 million, Belgium, Switzerland and Sweden are all ranked in the first half, and they total 14 percent of all eminent economists. But some other small countries do not do so well: 
Norway, Denmark, Austria and Ireland are among the worst ranked. This result suggests that size certainly does not guarantee many eminent economists, but smallness does not prevent a good ranking.

The distribution of eminent economists can, of course, be grouped in many more ways. One possibility would be to set the "Northern European" countries (UK, NL, B, S, N, DK, EIR) totaling a share of 73 percent against the "Middle" countries (F, D, CH, A, H) with 19 percent, and the "Southern European" countries (I, E, GR, P) with 8 percent.

The distribution according to language groups would set the English speaking UK and Ireland with a share of 58 percent against the Latin countries (F, I, E, P, half of B, and $3 / 7^{\text {th }}$ of $\mathrm{CH}$ ) with 20 percent, the Germanic countries (D, A, NL, half of B, and 4/7 $7^{\text {th }}$ of $\mathrm{CH}$ ) with 16 percent, the Scandinavian countries $(\mathrm{S}, \mathrm{N}, \mathrm{DK})$ with 6 percent, and the others $(\mathrm{H}, \mathrm{GR})$ with 1 percent.

\section{Influence of Country Size}

To become an eminent economist requires talent, i.e. one must have an appropriate genetic endowment. A natural presumption is that the population of all nations has an equal capacity in this respect ${ }^{9}$ (an alternative would be that some populations are better endowed with scientific, or at least economic, talent, but then the question arises which countries these are, and what the reason is for this). We thus have

Hypothesis 1: The number of eminent economists is proportional to the size of the population.

\footnotetext{
${ }^{8}$ Directly relevant contributions are by Propper and Dasgupta (2000), Machin and Oswald (2000), Blank (2000) and Freeman (2000).

${ }^{9}$ See the contribution by Glejser (2000), who applies this idea to success in sports, in particular in the Olympic games.
} 
In order to test this hypothesis, the fourth column of table 1 shows the proportion of eminent economists weighted by the size of the population of the country they are attached to.

The table can best be interpreted by distinguishing three groups of countries: the United Kingdom as a special case; four large European countries (F, D, I, and E) with a population of more than 39 million each; and ten small European countries (NL, GR, H, B, S, A, CH, DK, $\mathrm{N}$, EIR) with a population of less than 16 million each.

(1) The United Kingdom. This country, with a population of 59 million and 91 eminent economists, still ranks first (the index of 1.55 is much larger than that of any other European country, the next highest being Belgium and Switzerland, with an index of 0.99). If one follows the argument of natural endowment, the UK population has a marked talent for becoming a much cited economist.

(2) Four large countries. Germany, France, Italy and Spain have a total a population of 236 million, but count only 33 eminent economists. They all drop back markedly in their ranking. France loses seven ranks (in the population weighted ranking it is in rank 9, according to the absolute ranking it was in rank 2); Germany loses eight ranks (it is now $12^{\text {th }}$, compared to $4^{\text {th }}$ ); Spain loses six ranks (now $15^{\text {th }}$, and last of all countries included in table 1 , compared to $9^{\text {th }}$ ); and Italy loses five ranks (now $10^{\text {th }}$, compared to $5^{\text {th }}$ ).

(3) Small countries. Seven of the ten countries in this set are clear winners. Norway moves up five ranks, Switzerland, Sweden and Ireland improve their position by four ranks, Denmark moves up three ranks, and Belgium and the Netherlands one rank. Taking into account the size of the population, the small countries are now dominant (always with the exception of the UK): they compactly occupy ranks 2 to 8 , and only then follows the first large country, France. Belgium and Switzerland jointly hold rank 2, followed by Sweden, 
Norway, the Netherlands, Denmark and Ireland. These seven countries total a population of 55 million, and are thus smaller than Germany, France or Italy individually, but they boast 36 eminent economists.

Three of the small European countries do not fare well. Interestingly enough they have (with the exception of NL and B) the largest populations in this set. Austria, Greece and Hungary all lose one rank in the population adjusted ranking. They have a total population of 29 million, but have only three eminent economists.

The results are clearly against the hypothesis of an equal distribution of talent according to genetic endowment. The small countries do much better, while the large countries - with the exception of the United Kingdom - do much worse than they should according to their population endowment. This "small country effect" suggests that other factors must be at work.

\section{Influence of Economic Capacity}

The number of eminent economists may depend on the financial resources they have at their disposal, reflected e.g. in the facilities where they work, computer installment, and the number of well-educated collaborators. This suggests

Hypothesis 2: The number of eminent economists is proportional to GNP.

The fifth column of table 1 exhibits the corresponding figures and rankings (GNP across countries are made comparable by using PPP).

Again, distinguishing the same three groups of countries, the following observations may be made: 
(1) United Kingdom. This country is still on top, with a large gap before the second ranked Belgium (index 8.4 compared to 4.3 ).

(2) Four large countries. They again drop back compared to the ranking based on the absolute number of eminent economists. Germany loses ten, France eight, Italy seven, and Spain five ranks. They occupy the low ranks of ten, twelve and (twice) fourteen.

(3) Small countries. As before, weighing by per capita GNP strongly improves the ranking of these countries. Norway moves up five ranks compared to the absolute numbers; Sweden, Ireland and Hungary four; Switzerland, Denmark and Hungary three ranks; and the Netherlands and Greece one rank. Belgium maintains rank two behind the UK. They solidly occupy ranks two to nine, and only then comes the best ranked large Continental country, France, with rank ten. The only small country ranking slightly worse is Austria, which drops from rank twelve to rank thirteen.

These results suggest that endowment with material resources is not decisive for the number of eminent economists. The United Kingdom can boast the by far largest number of eminent economists per capita, though its per capita GNP of $\$ 17,800$ is rather low compared to Switzerland, Norway, Denmark and Belgium. In contrast, Germany and France, with a quite high per capita GNP of $\$ 20,500$ and $\$ 19,900$, respectively, are only ranked tenth and fourteenth. The richest five countries included in table $1(\mathrm{CH}, \mathrm{N}, \mathrm{DK}, \mathrm{B}$, and $\mathrm{A}$ in that order) occupy median rank five, while the poorest five (H, GR, E, EIR, and UK) occupy median rank eleven. While per capita GNP certainly does not explain the number of eminent economists across countries, it is nevertheless helpful.

The simultaneous influence of a country's size and income can also be analyzed in a multiple regressions approach. Although the results of regressions with so few data points have to be 
interpreted carefully, table 2 suggests that country size and income per capita exert independent, significant influences. This, however, is only true in an estimate which excludes the United Kingdom (column 2). When the United Kingdom is included (column 3), income as well as the country's size become insignificant. This result pinpoints the fact that the United Kingdom is an outlier when it is compared to Continental European countries.

TABLE 2 HERE

\section{The Top Twenty Economists According to Citations}

Table 3 lists the names and country of the twenty most often cited economists in Europe for the period 1993-1996.

\section{TABLE 3 HERE}

Also among these select few, the United Kingdom boast more than half ( 55 percent, i.e. almost the same as in the overall set of eminent economists). The four large Continental countries F, D, I, and E, with an overall population of 236 million, have a share of 20 percent, corresponding exactly to the share in the overall set. Five small countries (DK, H, AU, CH, and NL), with an overall population of 46 million, have one person each among the top twenty, with a total share of 25 percent. Surprisingly, Belgium is not represented, though it has ten eminent economists. Sweden has five eminent economists, but none makes the top twenty. In contrast, Hungary has only one eminent economist, but he is among the select twenty.

\section{Other Distributions of Eminence}


What constitutes an "eminent" economist can, of course, be identified other than by counting journal citations. An obvious candidate is the distribution of Nobel Prizes in economics. For the Nobel Prize, the period 1993 - 96 is, of course, too restricted to provide much evidence (in this period, six Americans, one Britisher, and one German received a Nobel Prize in economics). From 1969 up to 1999, 44 Prizes were given of which 68 percent to Americans (which is actually identical to Blaug's (1999) 68 percent share of Americans among the world's eminent economists), 14 percent to Britishers, and 18 percent to scholars working in other European countries (two each for Sweden and Norway, one each to the Netherlands, France, Russia and Germany). The UK is somewhat under-represented (it received 43 percent of the European Nobel Prizes in Economics, compared to its citation share of 57 percent), and accordingly the other countries are over-represented among the Europeans. The non-UK European countries with economics Nobel prize winners are strongly over-represented (they received 57 percent of the Prizes, but comprise only 18 percent of the citations).

Table 4 looks at another perspective. It presents the proportion of nations in the 36 (or 37) Council of the European Economic Association over our period 1993-96.

\section{TABLE 4 HERE}

It could be argued that the selection of the council members by all the members of the European Economic Association as the electorate also signals "eminence" according to professional standards (but, of course, the selection of candidates already takes into account that the various countries are "appropriately" represented). The UK, which dominates European citations (57 percent of all eminent economists according to citations), takes only about a quarter of the seats in the Council. The large Continental countries (F, D, I, E) take 42 percent, which is more than double their share in eminent economists according to citations (20.5 percent). The other small European countries (now including Finland and Iceland) 
occupy 35 percent of the seats, which is also remarkably higher than their share in eminence by citation (23 percent). Although the larger Continental countries are catching up a little bit, the small country effect is even more prevalent in this count. Compared to population size, every small (North)Western-European country (except Luxembourg) hosts more members of the Council of the European Economic Association than any of the large Continental countries does. And, most notably, not only do they all come close to the United Kingdom, but Belgium, Switzerland, Sweden, Norway, Finland and Iceland are even overtaking the UK. Those six countries provide for 28 percent of the seats, although they have only a total population of 36 million. This contrasts well with the 23 percent of the UK, with a population of 59 million, as well as to France (14 percent and 58 million inhabitants), Italy (12 percent and 57 million), and Germany ( 9 percent and 82 million).

\section{Robustness Check}

Are the results, in particular the small country effect, steered by our data selection procedure? We believe this not to be the case. On the one hand, the above discussion demonstrates that the small country effect also shows up in various other measures of eminence. On the other hand, we have identified this effect in various sub-samples of our data. This is not only true with respect to the selection of the most influential economists, but also with regard to another sample which looks at publications and citations in the periods 1988-90 and 1986-90, respectively (see Eichenberger, Arpagaus and Meier 2000, p.151f.). Moreover, the small country effect can also be found in Blaug's data (Frey and Eichenberger 2000). Finally, our results are also robust with respect to the selection of the scientific journals included. We have recalculated the shares in the basic set for each country for different selections of journals. It turns out that the small countries are not favored by any particular journal (see Eichenberger, 
Meier, and Arpagaus 2000, p. 154). In contrast, if anything, the British result is biased by the fact that the Economic Journal gives UK economists a definite advantage.

\section{Conclusion}

Consider the problem that a country needs or wants to form a committee of twenty eminent national economists, i.e. those most recognized by their colleagues in terms of citations in scientific writings. The only country which can match this task is the United Kingdom (actually, it could man a committee of ninety). If the committee should be composed of ten persons, in addition to the UK, France and Belgium would be successful. With only five members, eight European countries would be able to complete the task. The question is, of course, whether committees of such size are ever needed and whether they have to be composed of eminent economists. If a country has not a sufficient number of eminent economists, they can resort to international exchange and can invite foreigners onto the committee. This is what is indeed often done, not to speak of completely international groups, for instance in the context of OECD. Yet another question is whether the advice offered by a group of eminent economists is any better than that provided by less frequently cited economists.

In general, therefore, the interest in having eminent economists derives mainly from their achievement as individuals rather than as a group ${ }^{10}$. The absolute number is not the only aspect of interest. But, from all points of view, the United Kingdom stands out: it occupies first rank in Europe according to absolute number, per capita, and GNP per capita. Several small countries do very well indeed: Belgium always ranks second or third, Switzerland and

\footnotetext{
${ }^{10}$ Unlike sports, where (sometimes, e.g. at the Olympics or at European or World championships) teams composed of nationals have to be formed. A particular country must, for instance, put together a team of eleven football players, and it is therefore important to have at least that number of "eminent" players available (Glejser 2000). However, even in that sport, teams are often composed of players from many different nationalities, an example being the immensely popular European football club championships.
} 
Sweden are ranked well, especially when the small size of their population is taken into account. These countries are at the same time among the rich ones. Small but poor countries (Hungary, Greece) are badly ranked in all respects. The four large Continental European countries only do well according to the absolute number of eminent economists. But weighted by population size and GNP they chop back dramatically. The percentage of eminent economists in the three European country groups - the United Kingdom, the four large and the ten small countries - is almost identical for the more select set of the top twenty. 


\section{References}

Arpagaus, Rolf, 1998. Die Publikationen und Zitationen Europäischer Ökonomen: 1993-1996. Diploma Thesis, University of Zurich.

Blank, Rebecca M., 2000. The State of British Economics. Economic Journal 110 (June), F350-F354.

Blaug, Mark and Paul Sturges (eds.), 1983. Who's Who in Economics? A Biographical Dictionary 1700-1981. Brighton: Wheatsheaf.

Blaug, Mark (ed.), 1986. Who's Who in Economics? A Biographical Dictionary of Major Economists 1700-1986 ( $2^{\text {nd }}$ edition). Brighton: Wheatsheaf.

Blaug, Mark (ed.), 1999. Who's Who in Economics? ( ${ }^{\text {rd }}$ ed.) Cheltenham: Edward Elgar.

Bommer, Rolf and Heinrich W. Ursprung, 1998. Spieglein, Spieglein an der Wand. Eine publikationsanalytische Erfassung der Forschungsleistungen volkswirtschaftlicher Fachbereiche in Deutschland, Österreich und der Schweiz. Zeitschrift für Wirtschaftsund Sozialwissenschaften 118, 1-28.

De Lorme, C. D. and D.R. Kamerschen, 1987. What Who's Who in Economics tells us about the economics profession. Quarterly Review of Economics and Business 27 (4), 65-79.

Dusansky, R. and C.J. Vernon, 1998. Rankings of U.S. Economics Departments. Journal of Economic Perspectives 12 (1, Winter), 157-170.

Eichenberger, Reiner and Ursina Meier, 1996. Ökonomen, Publikationen und Zitationen: Ein europäischer Vergleich. Unpublished Manuscript, University of Zurich.

Eichenberger, Reiner, Ursina Meier and Rolf Arpagaus, 2000. Ökonomen, Publikationen und Zitationen: Ein europäischer Vergleich. Perspektiven für Wirtschaftspolitik 1, 143-160.

Freeman, Richard B., 2000. The Changing State of Economics in the United Kingdom and the United States". Economic Journal 110, F355-F357.

Frey, Bruno S. and Werner W. Pommerehne, 1988. The American Domination Among Eminent Economists. Scientometrics 14, 97-110.

Frey, Bruno S. and Reiner Eichenberger, 2000. Who's Who in Economics? A Note on Mark Blaug's Compendium. Kyklos (forthcoming).

Glejser, Herbert, 2000. Decreasing returns to scale for the small country due to scarcity or indivisibility - A test on sport. CESifo Working Paper No. 294.

Grubel, Herbert G., 1979. Citation Counts for Leading Economists", Economic Notes by Monte dei Paschi di Siena 2, 134-45. 
Kalaitzidakis, Pantelis, Theofanis P. Mamuneas and Thanasis Stengos, 1999. European Economics; An Analysis based on publications in the core journals. European Economic Review 43, 1150-168.

Kocher, Martin G. and Matthias Sutter, 2000. The Market for Publications in Top Economics Journals. Economic Journal (forthcoming).

Laband, David N., 1985. An Evaluation of 50 "Ranked" Economics Departments - By Quantity and Quality of Faculty Publications and Graduate Student Placements and Research Success. Southern Economic Journal 52, 216-240.

Laband, David N. and Michael J. Piette, 1994. The Relative Impact of Economics Journals. Journal of Economic Literature 32, 650-666.

Lindbeck, Assar, 1999. The Sveriges Riksbank (Bank of Sweden) Prize in Economic Sciences in Memory of Alfred Nobel 1969-1998. http://www.nobel.se/economics/articles/lindbeck/index.html

Machin, Stephen and Andrew Oswald, 2000. UK Economics and the Future Supply of Academic Economists". Economic Journal 110, F334-F349.

Propper, Carol and Partha Dasgupta, 2000. The State of British Academic Economics Editorial Introduction. Economic Journal 110, F291-292.

Quandt, Richard, 1976. Some Quantitative Aspects of the Economic Journal Literature, Journal of Political Economy 84, 741-55. 
Table 1: Eminent Living European Economists according to Country, Classification based on Citations, 1993-1996

\begin{tabular}{|c|c|c|c|c|c|c|c|}
\hline \multirow{3}{*}{$\begin{array}{c}\text { country } \\
\text { United Kingdom }\end{array}$} & \multicolumn{3}{|c|}{ unweighted numbers } & \multicolumn{4}{|c|}{ weighted numbers ${ }^{\mathrm{a}}$} \\
\hline & \multicolumn{2}{|c|}{$\begin{array}{l}\text { absolute } \\
\text { number } \\
(\mathrm{N}=160)\end{array}$} & \multirow{2}{*}{$\begin{array}{c}\begin{array}{c}\text { percentage } \\
\text { of total } \\
\text { number }\end{array} \\
56.88\end{array}$} & \multicolumn{2}{|c|}{$\begin{array}{c}\text { by population } \\
\text { (absolute number } \\
\text { per million } \\
\text { inhabitants) }\end{array}$} & \multicolumn{2}{|c|}{$\begin{array}{l}\text { by GNP } \\
\text { (absolute number } \\
\text { per } \$ 100 \text { billion) }\end{array}$} \\
\hline & 91 & (1) & & 1.55 & (1) & 8.74 & (1) \\
\hline France & 13 & (2) & 8.13 & 0.22 & (9) & 1.12 & (10) \\
\hline Belgium & 10 & (3) & 6.25 & 0.99 & (2) & 4.74 & (2) \\
\hline Germany & 9 & (4) & 5.63 & 0.11 & (12) & 0.54 & (14) \\
\hline Italy & 8 & (5) & 5.00 & 0.14 & $(10)$ & 0.72 & (12) \\
\hline Switzerland & 7 & (6) & 4.38 & 0.99 & (2) & 3.98 & (3) \\
\hline Netherlands & 6 & (7) & 3.75 & 0.39 & (6) & 1.96 & (6) \\
\hline Sweden & 5 & (8) & 3.13 & 0.57 & (4) & 3.03 & (4) \\
\hline Spain & 3 & (9) & 1.88 & 0.08 & (15) & 0.54 & (14) \\
\hline Norway & 2 & (10) & 1.25 & 0.46 & (5) & 2.02 & (5) \\
\hline Denmark & 2 & (10) & 1.25 & 0.38 & (7) & 1.78 & (7) \\
\hline Austria & 1 & (12) & 0.63 & 0.12 & (11) & 0.62 & (13) \\
\hline Ireland & 1 & (12) & 0.63 & 0.28 & (8) & 1.62 & (8) \\
\hline Hungary $^{\mathrm{c}}$ & 1 & (12) & 0.63 & 0.10 & (13) & 1.53 & (9) \\
\hline Greece & 1 & (12) & 0.63 & 0.10 & (13) & 0.79 & (11) \\
\hline
\end{tabular}

numbers in parantheses indicate the ranks

a data for 1995; Source: OECD in Figures, Paris, 1997

$\mathrm{b}$ at current prices in $\$$ using current PPPs

${ }^{c}$ data from World Development Report, New York 1997 
Table 2: The Country Output of Eminent Economists

\begin{tabular}{lcc}
\hline \hline & $\begin{array}{c}\text { sample excluding UK } \\
(\mathrm{n}=15)\end{array}$ & $\begin{array}{c}\text { sample including UK } \\
(\mathrm{n}=14)\end{array}$ \\
& -0.222 & -.1729 \\
& $(-0.833)$ & $(-0.352)$ \\
constant & -0.00557 & -0.00057 \\
& $(-2.158)$ & $(-0.128)$ \\
country size & 0.000038 & 0.000034 \\
(in million inhabitants) & $(2.742)$ & $(1.319)$ \\
GNP per capita in PPP & & $\mathrm{R}^{2}=-0.0184$ \\
(in US\$) & $\mathrm{R}^{2}=0.4243$ & \\
\hline \hline
\end{tabular}

dependent variable is eminent economists per million inhabitants numbers in parantheses indicate the t-values 
Table 3: Europe's Top 20 Economists (1993-96)

\begin{tabular}{|c|c|c|c|}
\hline name & $\begin{array}{c}\text { year of } \\
\text { birth }\end{array}$ & country & citations \\
\hline Søren Johansen & 1939 & DK & 1232 \\
\hline Anthony B. Atkinson & 1944 & UK & 898 \\
\hline Partha S. Dasgupta & 1942 & UK & 775 \\
\hline Janos Kornai & 1928 & $\mathrm{H}$ & 753 \\
\hline David F. Hendry & 1944 & UK & 708 \\
\hline Jean Tirole & 1953 & $\mathrm{~F}$ & 657 \\
\hline Jean-Jacques Laffont & 1947 & $\mathrm{~F}$ & 567 \\
\hline Ken Binmore & 1940 & UK & 544 \\
\hline Andrew Harvey & 1947 & UK & 523 \\
\hline John H. Dunning & 1927 & UK & 518 \\
\hline Dennis C. Mueller & 1940 & Ö & 515 \\
\hline Giovanni Dosi & 1953 & I & 502 \\
\hline Reinhard Selten & 1930 & $\mathrm{D}$ & 494 \\
\hline David W. Pearce & 1941 & UK & 457 \\
\hline Bruno S. Frey & 1941 & $\mathrm{CH}$ & 405 \\
\hline Stephen J. Nickell & 1944 & UK & 397 \\
\hline Philippe Aghion & 1956 & UK & 392 \\
\hline Mark Blaug & 1927 & UK & 388 \\
\hline M. Hashem Pesaran & 1948 & UK & 370 \\
\hline Angus Maddison & 1926 & NL & 367 \\
\hline
\end{tabular}


Table 4: Percentage of nations represented in the Council of the European Economic Association. Average over the period 1993-1996, in percent

\begin{tabular}{lc}
\hline \hline Country & percentage share \\
\hline United Kingdom & 23.27 \\
France & 13.70 \\
Belgium & 10.29 \\
Germany & 8.88 \\
Italy & 11.66 \\
Switzerland & 4.81 \\
Netherlands & 2.74 \\
Sweden & 5,46 \\
Spain & 7.55 \\
Norway & 2.07 \\
Denmark & 1.35 \\
Austria & 2.74 \\
Ireland & - \\
Hungary & - \\
Greece & - \\
Others (Finland, Iceland) & 5.46 \\
& \\
\hline \hline Note: The listing of countries corresponds to the one in Table 1. \\
The Council consisted of 37 members in 1993 and 1996, and of \\
$\begin{array}{l}\text { president-elect, vice-president, past president, secretary and } \\
\text { treasurer). }\end{array}$ \\
\hline
\end{tabular}

